Report of Investigation 2018-1

\title{
CHANNEL MIGRATION STUDY OF EMMONAK, ALASKA
}

Jacquelyn R. Overbeck and Katrina S. Kennedy

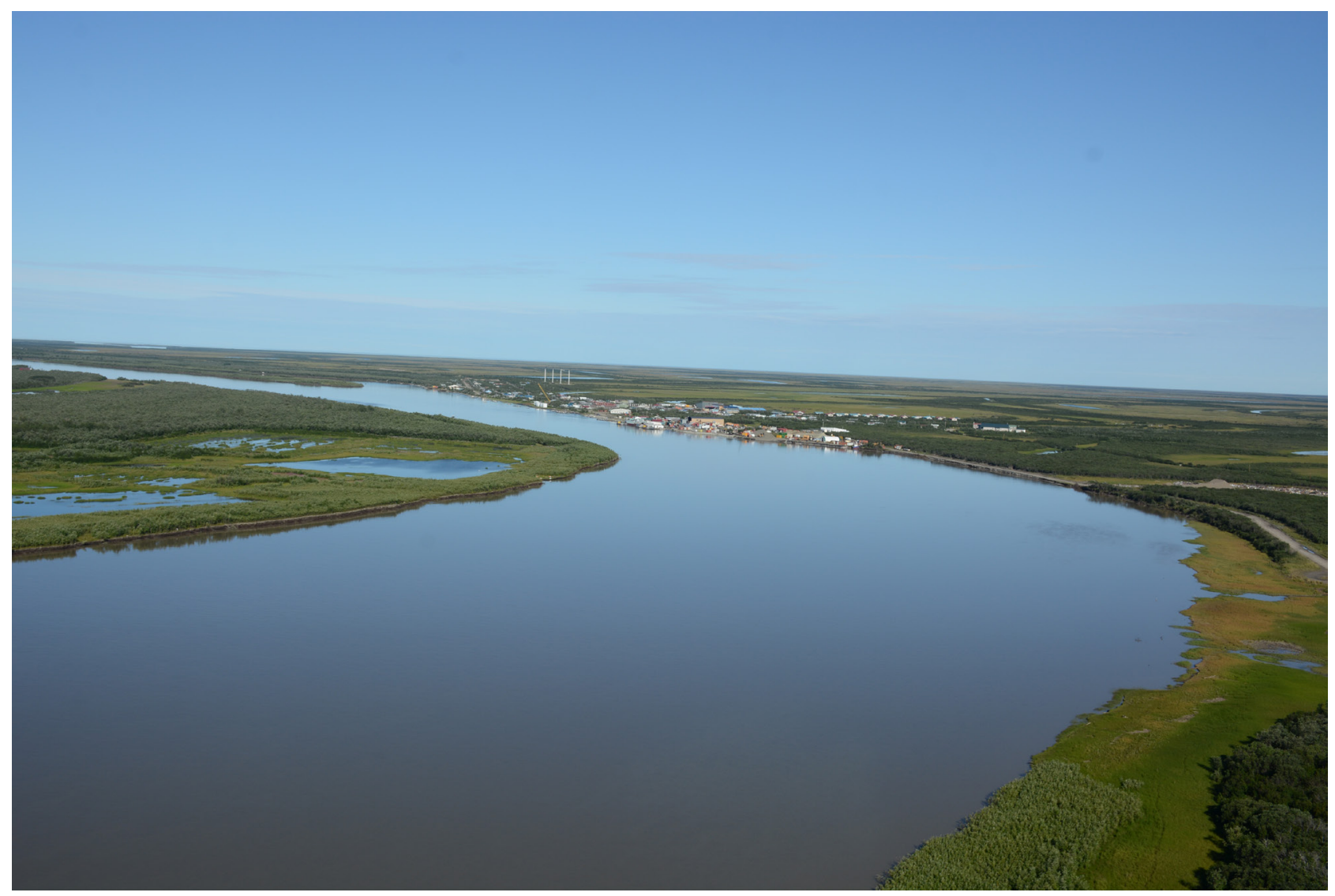

Oblique photo of Emmonak, Alaska (photo courtesy of shorezone.org).

Published by

STATE OF ALASKA

DEPARTMENT OF NATURAL RESOURCES

DIVISION OF GEOLOGICAL \& GEOPHYSICAL SURVEYS

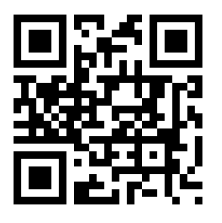


This page intentionally left blank. 


\section{CHANNEL MIGRATION STUDY OF EMMONAK, ALASKA}

Jacquelyn R. Overbeck and Katrina S. Kennedy

Report of Investigation 2018-1

State of Alaska

Department of Natural Resources

Division of Geological \& Geophysical Surveys 


\title{
STATE OF ALASKA
}

Bill Walker, Governor

\section{DEPARTMENT OF NATURAL RESOURCES}

Andrew T. Mack, Commissioner

\section{DIVISION OF GEOLOGICAL \& GEOPHYSICAL SURVEYS}

\author{
Steve Masterman, State Geologist and Director
}

Publications produced by the Division of Geological \& Geophysical Surveys (DGGS) are available for free download from the DGGS website (dggs.alaska.gov). Publications on hard-copy or digital media can be examined or purchased in the Fairbanks office:

Alaska Division of Geological \& Geophysical Surveys 3354 College Rd., Fairbanks, Alaska 99709-3707

Phone: (907) 451-5010 Fax (907) 451-5050

dggspubs@alaska.gov|dggs.alaska.gov

DGGS publications are also available at:

Alaska State Library, Historical Collections \& Talking Book Center 395 Whittier Street Juneau, Alaska 99811

Alaska Resource Library and Information Services (ARLIS) 3150 C Street, Suite 100

Anchorage, Alaska 99503

Suggested citation:

Overbeck, J.R., and Kennedy, K.S., 2018, Channel migration study of Emmonak, Alaska: Alaska Division of Geological \& Geophysical Surveys Report of Investigation, 2018-1, 11 p., 2 sheets. http://doi.org/10.14509/30114

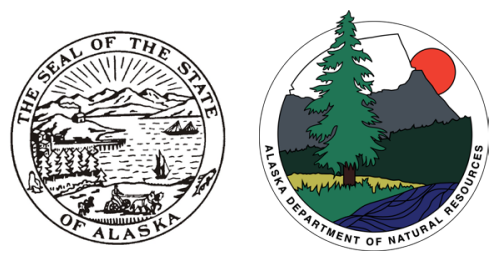




\section{Contents}

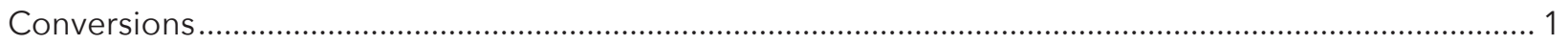

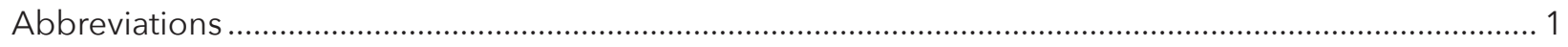

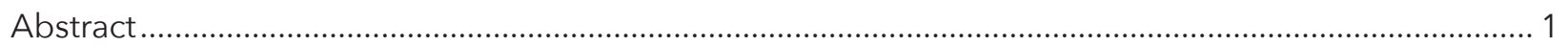

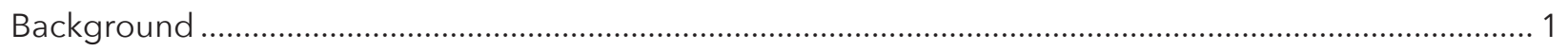

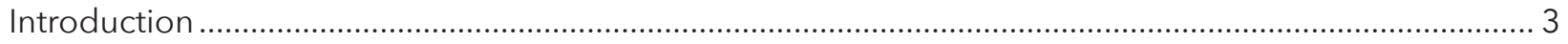

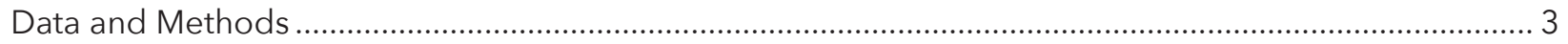

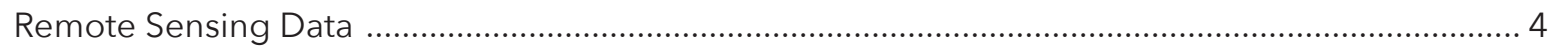

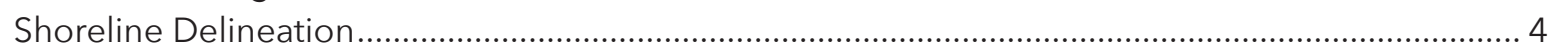

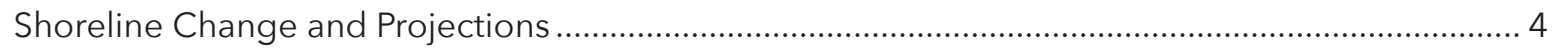

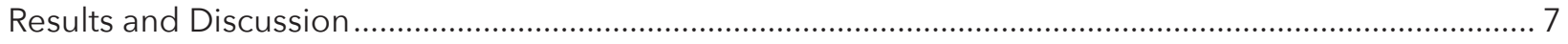

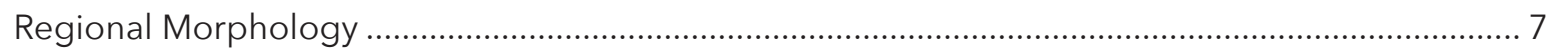

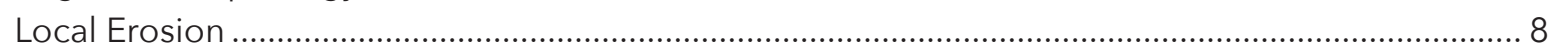

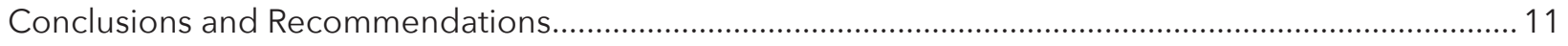

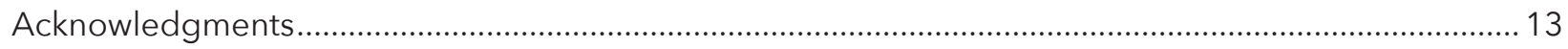

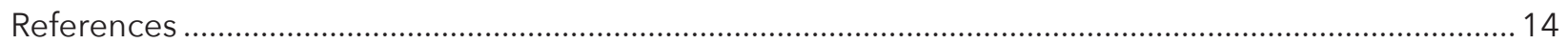

\section{Figures}

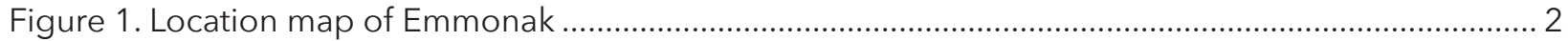

Figure 2. Example of wet/dry line (MHW) points identified on 2015 orthoimagery that were

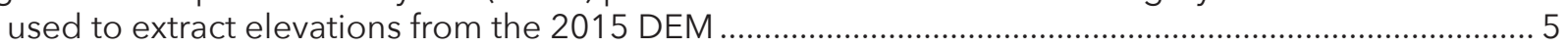

Figure 3. Elevations extracted from the 2015 DEM using visually-interpreted mean high water shorelines on sandy beaches near Emmonak .............................................................................. 5

Figure 4. Differences in the visually-delineated shoreline from 2015 and elevation-extracted shoreline from 2016 at a location expected to be stable, and a location with observed

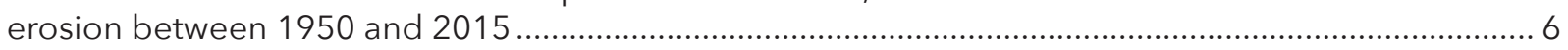

Figure 5. River shorelines interpreted from aerial and satellite imagery showing regional changes........ 7

Figure 6. Elevation data for the area surrounding Emmonak, including a lidar bare earth model and a photogrammetrically-derived surface model, superimposed on a satellite image ......... 9

Figure 7. Net shoreline movement at cross-shore profile locations at the village of Emmonak .............. 10

Figure 8. Shoreline positions fronting the city dock at Emmonak showing shoreline erosion from 1950-2006, then shoreline stabilization from 2006-2016 .......................................................... 11

Figure 9. Shoreline positions along DSAS transects through time ......................................................... 12

\section{Tables}

Table 1. Measures of uncertainty used to determine positional uncertainty of shoreline data................. 6

Table 2. Statistics of shoreline change parameters along Emmonak shoreline ....................................... 10

\section{Map Sheets}

Sheet 1: Shoreline Change (1950-2016) at Emmonak, Alaska

Sheet 2: Projected Future Shorelines (2020-2030) at Emmonak, Alaska 
This page intentionally left blank. 


\title{
CHANNEL MIGRATION STUDY OF EMMONAK, ALASKA
}

\author{
Jacquelyn R. Overbeck ${ }^{1}$ and Katrina S. Kennedy ${ }^{1}$
}

1 meter $=3.281$ feet

\section{Conversions}

$\begin{array}{ll} & \text { Abbreviations } \\ \text { DCRA = Alaska Division of Community } & \text { lidar }=\text { light detection and ranging } \\ \text { and Regional Affairs } & \text { MHW = mean high water tidal datum } \\ \text { DEM = digital elevation model } & \text { NAVD88 = North American Vertical } \\ \text { DSAS = Digital Shoreline Analysis } & \text { Datum of } 1988 \\ \text { System } & \text { NSM = net shoreline movement } \\ \mathrm{ft}=\text { feet } & \text { orthoimagery = orthorectified aerial } \\ \mathrm{km}=\text { kilometers } & \text { imagery } \\ \mathrm{m}=\text { meters } & \text { WLR = weighted linear regression }\end{array}$

\begin{abstract}
The rural village of Emmonak, located on Kwiguk Pass of the Yukon River, Alaska, experiences both erosion and aggradation of river shorelines due to channel migration. The proximity of Emmonak to a major bend in the Yukon River makes the community vulnerable to changes in river morphology that could divert or change flow volumes through Kwiguk Pass due to flood events. This study uses remote sensing datasets spanning 1950-2016 to examine changes to the shorelines and project potential future shoreline positions for near-term planning (2020, 2025, and 2030). River erosion was most dramatic and has persisted east of the Emmonak city dock, with as much as $175 \mathrm{~m}$ ( $574 \mathrm{ft}$ ) of erosion between 1950 and 2016. A road, which fronts the river east of the city dock and links the village and airport, is likely to be impacted by erosion by 2020. Erosion is not as persistent or dramatic downstream of the community, although the river has historically migrated to produce both eroding and aggrading shorelines that change by $+/-1 \mathrm{~m} /$ year (3.3 ft/year).
\end{abstract}

\section{BACKGROUND}

The village of Emmonak is located on Kwiguk Pass, a distributary of the Yukon River on the western reaches of the Yukon River delta (fig. 1). Emmonak is a Yup'ik Eskimo village (population 845) reliant on commercial and subsistence fishing and fish processing (Alaska Division of Community and Regional Affairs, 2017). The community was relocated $2.25 \mathrm{~km}$ (1.4 miles) north of the former Kwiguk village location in 1964-1965 due to erosion and flooding (Alaska Division of Community and Regional Affairs, 2017). The main Yukon
River channel, feeding Kwiguk Pass, flows to the south and exits into the Bering Sea. Since 1972, the channel has migrated to the north, towards Emmonak, forming a densely vegetated point bar to the south and prominent cutbank at the mouth of Kwiguk Pass (Macander and others, 2014). Cutbanks that sharply change direction on the Yukon River are prime locations for ice jam flooding during spring breakup which, when released, can result in river bank erosion and/or the formation of new river channels.

\footnotetext{
${ }^{1}$ Alaska Division of Geological \& Geophysical Surveys, 3651 Penland Parkway, Anchorage, AK, 99508
} 
The comparatively narrow channel of Kwiguk Pass (to the Yukon River) has also been subject to ice jams, which have resulted in flooding of the community (for example, the event documented in 1995, from photo in STARR, 2015). In addition to ice jam flooding, Emmonak's proximity to the Bering Sea makes the community prone to storm surge as well as flooding from spring melt and rainfall runoff (City of Emmonak, 2014), all of which can result in riverbank erosion. During winter months the Yukon River delta is surrounded by sea ice, which is expected to form increasingly later in the year in response to warming climate (Douglas, 2010). This leaves coastal waters exposed to storm activity. Regularly-occurring fall and winter coastal storms are expected to increase flooding and erosion due to loss of protection from offshore sea ice and nearshore land fast ice (Vermaire and others, 2013).

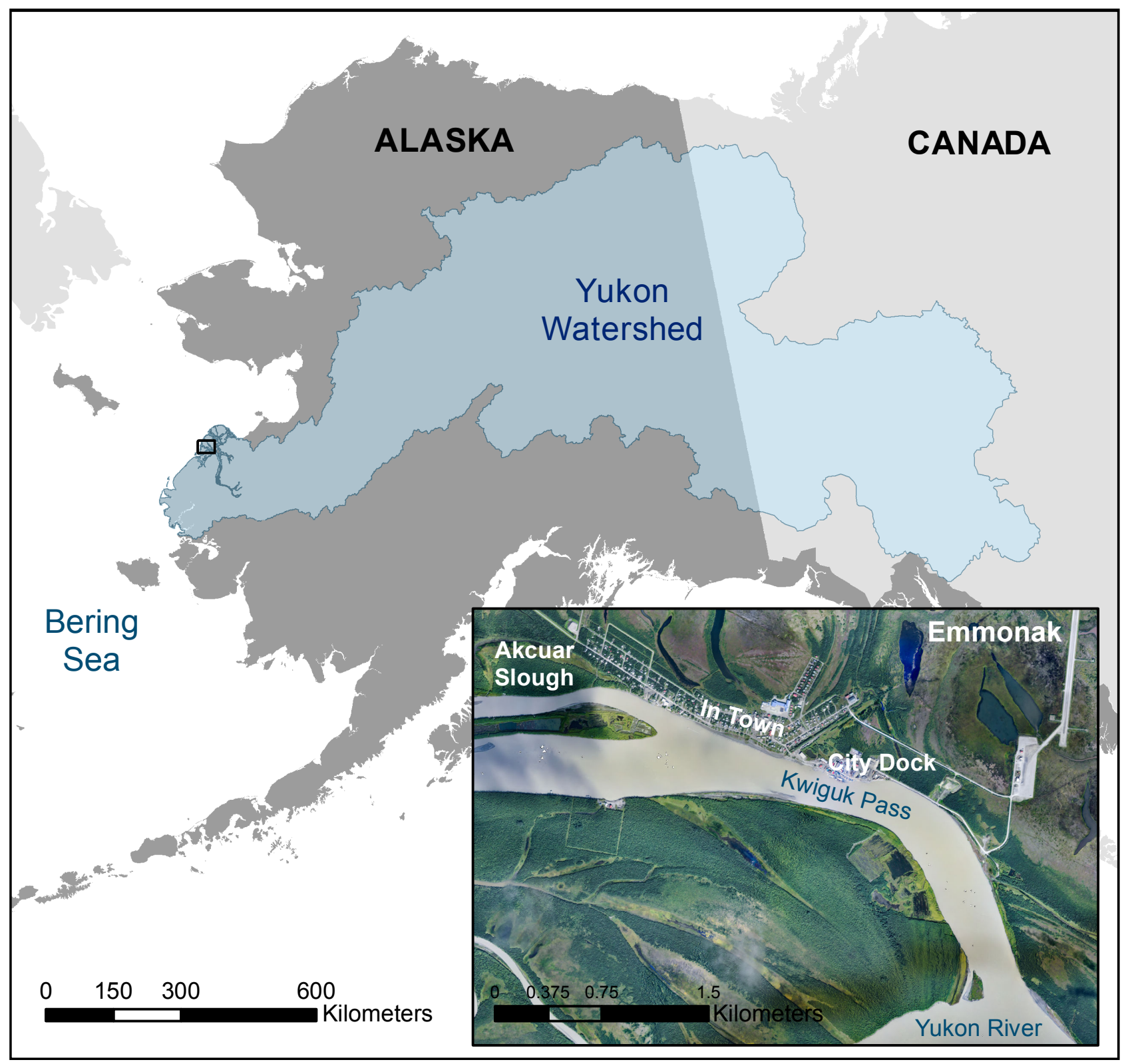

Figure 1. Location map of Emmonak showing geographic features referenced in text. Base imagery for the inset is the 2015 orthoimage. 
In addition to erosion from high water events, erosion at the community site may also be caused by wave action and currents, including those caused by boat wakes; annual freeze-thaw cycles that reduce soil cohesion; and foot traffic, which can destroy vegetation and prevent new growth (City of Emmonak, 2014). Emmonak is located in a region of isolated permafrost, meaning that up to 10 percent of the area may be underlain by perennially-frozen ground (permafrost) (Jorgensen and others, 2008). Upon thawing, fine-grained riverbank sediments are more likely to fail than other sediment types.

\section{INTRODUCTION}

River channel migration is a geomorphological process that involves the lateral migration of a river channel across its floodplain. This process is mainly driven by the combination of bank erosion and point bar deposition over time. Avulsion-the rapid abandonment of a river channel and formation of a new river channel-is typical in river systems in which the water dispersal pattern is distributive, or spreading out, as in deltas, alluvial fans, and submarine fans. Channels switch back and forth over time, distributing the sediment into a fan shape.

In its 2014 Local Hazard Mitigation Plan, the village of Emmonak identified erosion as being highly likely to adversely impact the community (City of Emmonak, 2014). Past studies of erosion in the area, including that of Macander and others (2014), were not of high enough resolution to determine alongshore vulnerability to channel erosion at the community level. The Alaska Division of Community and Regional Affairs (DCRA) prioritized a channel migration study, funded through the Federal Emergency Management Agency's (FEMA) Cooperating Technical Partners Program, to aid in community decision making regarding erosion hazards. The Alaska Division of Geological \& Geophysical Surveys (DGGS) completed this study to address community and state priorities.

At a regional scale, we use moderate-resolution satellite imagery (ca. 2010) and high-resolution aerial imagery (ca. 1950) to identify large-scale changes to the Yukon River channel. Large-scale changes to river morphology are representative of long-term trends that can lead to major shifts in the location of primary river channels across a floodplain on a geologic timescale. Digital elevation models (DEMs) that show the earth's surface without vegetation were used to identify potential paths where water would flow during high water events. Major shifts in river morphology, such as avulsions, are more likely to occur during high water, when increased discharge can dramatically redistribute river sediments.

We use high-resolution imagery and elevation data to model the potential impacts of localized erosion to help inform site planning for potential mitigation structures and community planning for relocation of infrastructure. High-resolution orthorectified aerial imagery (orthoimagery; 1950, 1980, 2006, and 2015) and DEMs (2016) were used for this study; no field investigations were conducted to supplement the work. Our results show both regional sediment accretion and erosion as well as shoreline change rates along the riverbanks fronting the community of Emmonak. Shorelines have also been modeled to show their near-term potential future positions in 2020, 2025, and 2030. When combined with locations of community infrastructure and local knowledge about cultural resources, shoreline projections can be used to pinpoint critical areas vulnerable to future shoreline change.

\section{DATA AND METHODS}

Remote sensing data, including orthoimagery and DEMs from photogrammetry and light detection and ranging (lidar) are used to determine the position of the river shoreline near Emmonak for time periods between 1950 and 2016. We calculate rates of shoreline change between shoreline 
positions, as well as the net amount of change. We then use the rates of shoreline change to project potential future positions of the river shoreline to compare with locations of current infrastructure and land use areas. An online interactive map of the shoreline data and projected shorelines discussed in this report is available at http://maps. dggs.alaska.gov/shoreline/.

\section{Remote Sensing Data}

Multiple types and epochs of remote sensing data are available for the Emmonak area and used in our channel change study. In 2016 the U.S. Geological Survey (USGS) contracted Woolpert, Inc., to collect lidar over a large swath of the Yukon-Kuskokwim Delta and generate DEMs (DGGS Staff, 2013). Overbeck and others (2016) contracted Fairbanks Fodar to collect and orthorectify aerial photographs over the western coast of Alaska and in 2015 to produce digital surface models and orthoimagery for 26 communities (Overbeck and others, 2016). Orthoimagery collected in 2006 for DCRA community profile base maps is publicly available (Alaska Division of Community and Regional Affairs, 2017b). Historical aerial photographs from 1950 and 1980 over portions of western Alaska were orthorectified by a DGGS (1950 data) and USGS contractor (1980 data), Far North Geospatial, to provide snapshots of older shoreline positions. Geographic coverage of each dataset varies, however, all datasets cover the village of Emmonak.

\section{Shoreline Delineation}

We manually delineate shorelines in ArcGIS using orthoimagery to visually determine the location of the wet/dry line, which is most analogous to the Mean High Water (MHW) tidal datum (Gould and others, 2015). At locations where the riverbank has a vertical face into the water (cut bank), the shoreline is delineated as the edge of that bank.

Elevation data are also used to delineate shoreline positions. Delineating shorelines on elevation data is commonly conducted by automatically extracting the MHW elevation from the DEM.
For much of Alaska, however, tidal datums have not been computed. To determine the MHW elevation at Emmonak, the visible wet/dry line from the 2015 orthoimagery is converted to points along the shore (fig. 2). The elevation of the surface at the point is then extracted from the co-located DEM. The upper and lower 1 percent of the data are removed to remove the effects of outliers. The remaining 98 percent of the data have a median value of $2.3 \mathrm{~m}(7.55 \mathrm{ft})$ with the middle 10 percent of the data (45th-55th percentiles) ranging from $2.27 \mathrm{~m}$ to $2.33 \mathrm{~m}(7.45 \mathrm{ft}$ to $7.64 \mathrm{ft})$ relative to NAVD88 (GEOID12B; fig. 3). This median elevation is used to delineate the MHW shoreline from the lidar DEM for 2016. Where the shoreline was expected to be stable (rock revetment), the MHW elevations agree well between 2015 and 2016 datasets (fig. 4a). Where erosion is observed between 1950 and 2015, additional erosion is also observed between the 2015 and 2016 datasets (fig. 4b).

\section{Shoreline Change and Projections}

Changes to shoreline positions through time are computed at alongshore intervals using the USGS Digital Shoreline Analysis System (DSAS; Thieler and others, 2009). We cast DSAS transects from a baseline offshore of the shoreline data, perpendicular to the delineated shorelines. DSAS automatically computes the distance of the intersecting shorelines along each transect and converts those distances into rates of shoreline change, and the net shoreline movement (NSM) over the time period analyzed. The rate of shoreline change used here is the weighted linear regression (WLR) of the shoreline positions with a 90 percent confidence interval (Thieler and others, 2009). Similar to Kinsman and Gould (2014), we determine uncertainty in the position of each shoreline (by date) by summing the squares of contributing uncertainties in their physical location, resulting in a total uncertainty $\left(U_{t}\right)$. Shoreline uncertainties are computed from: (1) positional uncertainty of ground control used to reference imagery $\left(\mathrm{U}_{\mathrm{p}}\right)$; (2) orthorectification distortions $\left(\mathrm{U}_{\mathrm{O}}\right)$; (3) uncertainty in identifying 
the shoreline, dependent on pixel scale $\left(\mathrm{U}_{\mathrm{i}}\right)$; and digitizer operator error $\left(\mathrm{U}_{\mathrm{d}}\right.$; Kinsman and Gould, 2014; table 1). The WLR rate of shoreline change is used to project the position of the shoreline into the future (for years 2020, 2025, and 2030) from the most recent shoreline surveyed, using the ArcGIS tool created by Gould and others (2015). Following the methodology of Gould and others (2015), the 90 percent confidence interval values for the WLR rates of shoreline change are used to compute a buffer around the projected shoreline to show the physical uncertainty in the projection.

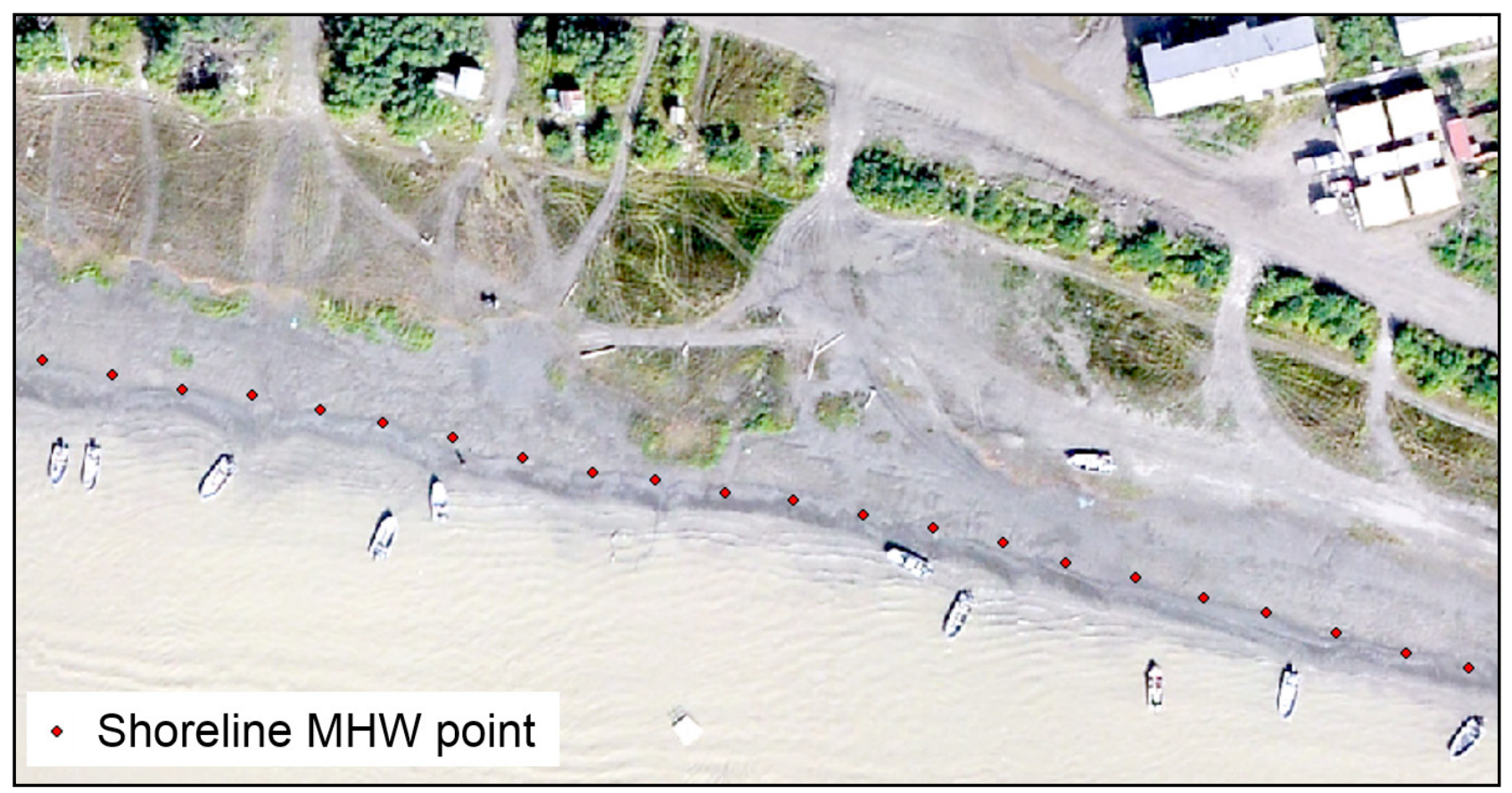

Figure 2. Example of wet/dry line (MHW) points identified on 2015 orthoimagery that were used to extract elevations from the 2015 DEM. Base imagery is the 2015 orthoimage.

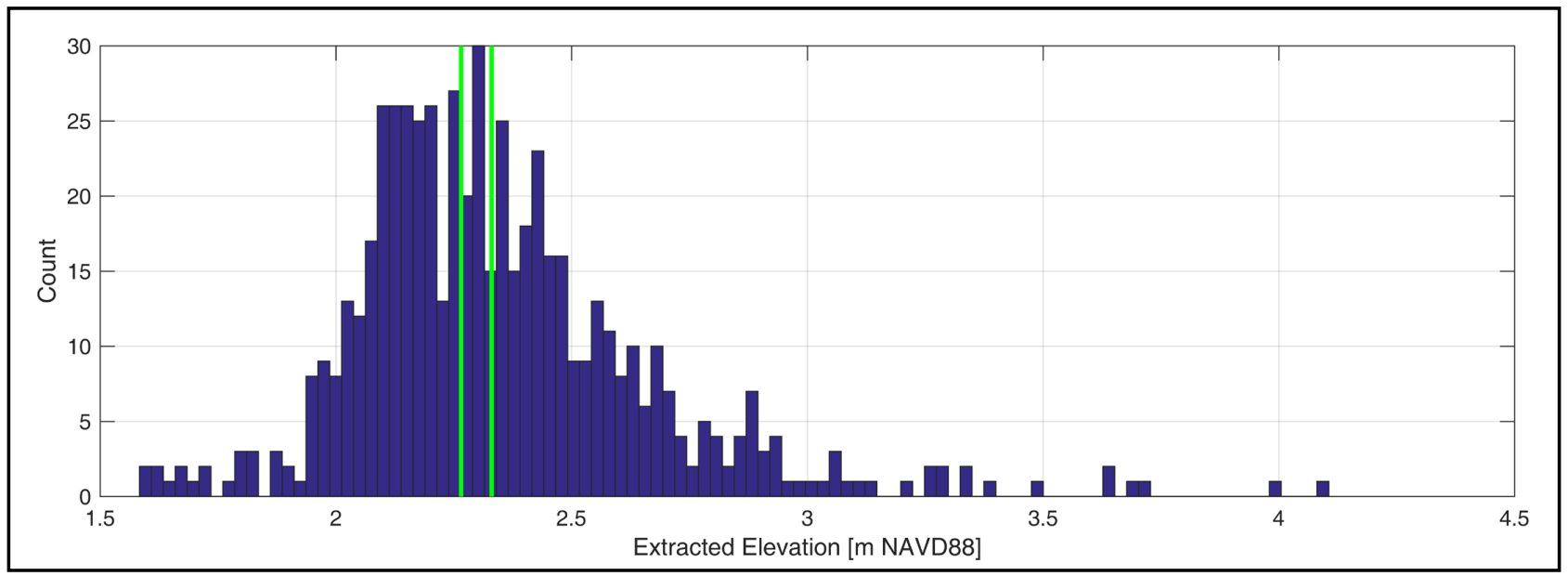

Figure 3. Elevations extracted from the 2015 DEM using visually-interpreted mean high water shorelines on sandy beaches near Emmonak. The green lines indicate the middle 10 percent of values extracted, the best estimate for MHW shoreline elevation (2.27-2.33 m [7.45-7.64 ft] NAVD88, median value of $2.30 \mathrm{~m}$ $[7.55 \mathrm{ft}])$. 


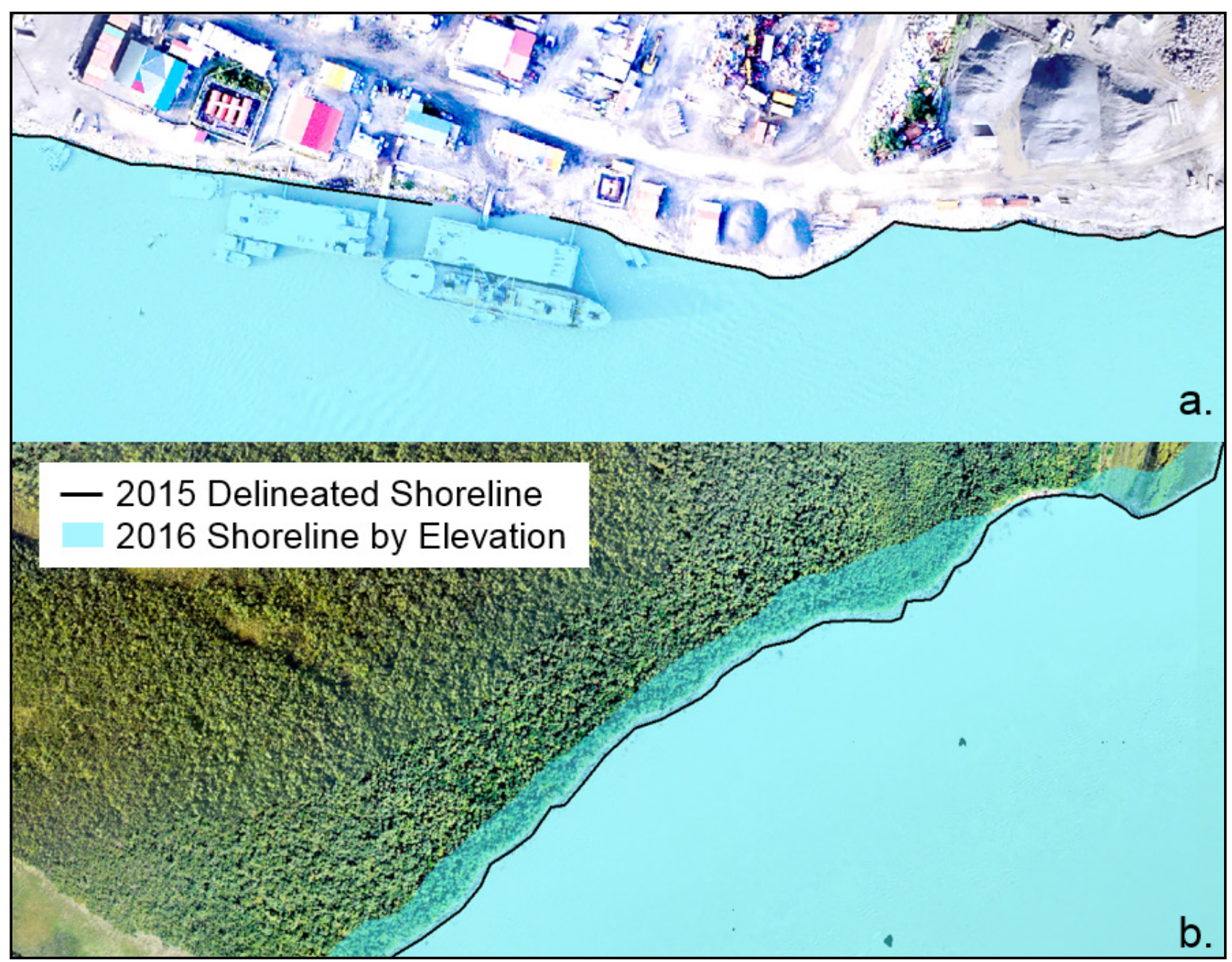

Figure 4. Differences in the visually-delineated shoreline from 2015 and elevation-extracted shoreline from 2016 at (a) a location expected to be stable, and (b) a location with observed erosion between 1950 and 2015. Base imagery is the 2015 orthoimage.

Table 1. Measures of uncertainty used to determine positional uncertainty of shoreline data.

\begin{tabular}{|c|c|c|c|c|c|c|}
\hline Shoreline & Type & $U_{p}$ & $U_{0}$ & $\mathrm{U}_{\mathrm{i}}$ & $\mathrm{U}_{\mathrm{d}}$ & $\mathrm{U}_{\mathrm{t}}$ \\
\hline 1950-June & Aerial Photo & $\begin{array}{l}0.170 \mathrm{~m} \\
0.558 \mathrm{ft}\end{array}$ & $\begin{array}{l}1.198 \mathrm{~m} \\
3.931 \mathrm{ft}\end{array}$ & $\begin{array}{l}1.000 \mathrm{~m} \\
3.281 \mathrm{ft}\end{array}$ & $\begin{array}{l}0.207 \mathrm{~m} \\
0.680 \mathrm{ft}\end{array}$ & $\begin{array}{l}1.583 \mathrm{~m} \\
5.194 \mathrm{ft}\end{array}$ \\
\hline 1980-July & Aerial Photo & $\begin{array}{l}0.170 \mathrm{~m} \\
0.558 \mathrm{ft}\end{array}$ & $\begin{array}{l}1.163 \mathrm{~m} \\
3.816 \mathrm{ft}\end{array}$ & $\begin{array}{l}1.700 \mathrm{~m} \\
5.578 \mathrm{ft}\end{array}$ & $\begin{array}{l}0.207 \mathrm{~m} \\
0.680 \mathrm{ft}\end{array}$ & $\begin{array}{l}2.077 \mathrm{~m} \\
6.815 \mathrm{ft}\end{array}$ \\
\hline 2006-August & Aerial Photo & - & $\begin{array}{l}0.800 \mathrm{~m} \\
2.625 \mathrm{ft}\end{array}$ & $\begin{array}{l}0.600 \mathrm{~m} \\
1.969 \mathrm{ft}\end{array}$ & $\begin{array}{l}0.207 \mathrm{~m} \\
0.680 \mathrm{ft}\end{array}$ & $\begin{array}{c}1.021 \mathrm{~m} \\
3.35 \mathrm{ft}\end{array}$ \\
\hline 2015-August & Aerial Photo & $\begin{array}{l}0.035 \mathrm{~m} \\
0.115 \mathrm{ft}\end{array}$ & $0 \mathrm{moft}$ & $\begin{array}{l}0.170 \mathrm{~m} \\
0.558 \mathrm{ft}\end{array}$ & $\begin{array}{l}0.207 \mathrm{~m} \\
0.680 \mathrm{ft}\end{array}$ & $\begin{array}{l}0.270 \mathrm{~m} \\
0.886 \mathrm{ft}\end{array}$ \\
\hline 2016-October & Lidar & $\begin{array}{l}0.044 \mathrm{~m} \\
0.144 \mathrm{ft}\end{array}$ & $0 \mathrm{moft}$ & $\begin{array}{l}2.000 \mathrm{~m} \\
6.562 \mathrm{ft}\end{array}$ & $\begin{array}{l}0.207 \mathrm{~m} \\
0.680 \mathrm{ft}\end{array}$ & $\begin{array}{l}2.011 \mathrm{~m} \\
6.598 \mathrm{ft}\end{array}$ \\
\hline
\end{tabular}




\section{RESULTS AND DISCUSSION Regional Morphology}

The Yukon River has eroded the mouth of Kwiguk Pass and the primary cutbank that shifts Yukon River discharge from northwest to southwest (fig. 5). The abrupt change in channel direction makes the region a likely location for ice jam formation. West of Emmonak, directional changes in Kwiguk Pass also make that area vulnerable to ice jams. Ice jams at these locations may result in backing up of river runoff from the Yukon River and flooding at Emmonak. When an ice jam flood releases, the event can be catastrophic. Flood waters follow the path of least resistance, and increased volume of flow can lead to water rushing through abandoned river channels and sloughs. Even when flood waters recede, newly formed channels may divert or increase existing flow.

River channel migration is concerning to the community of Emmonak, as the entire region is low relief with a high density of deltaic features, including sloughs, oxbow lakes, and abandoned river channels. Release of major flood waters has the potential to cause channel migration of the Yukon River cutoff, as well as the formation of a meander cutoff or channel avulsion. Bugomowik, Kwiguk, and Anuzukanuk passes are potential channels that could become occupied by greater river flow following a large ice jam flood event.

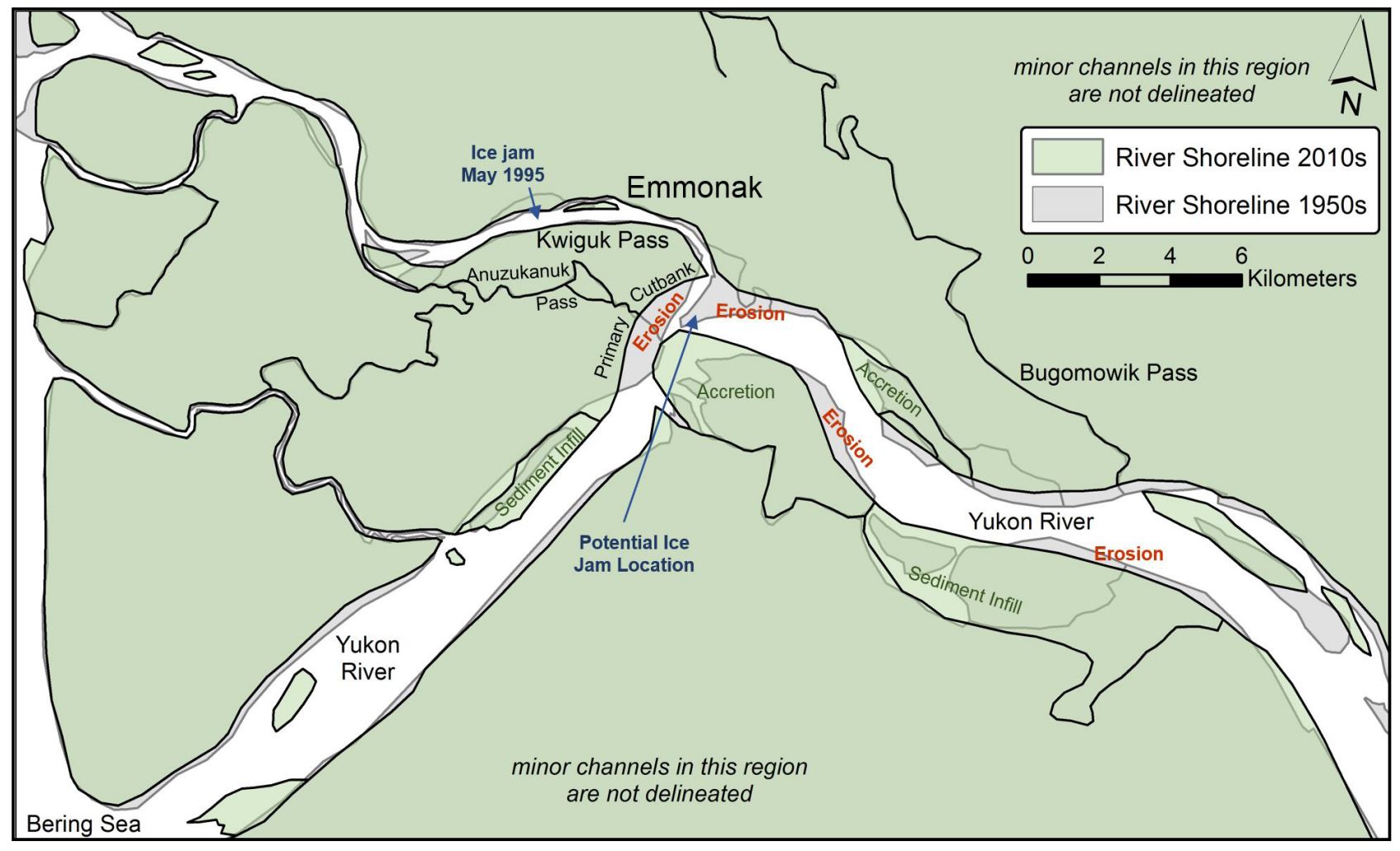

Figure 5. River shorelines interpreted from aerial (ca. 1950) and satellite (ca. 2010) imagery showing regional changes, including sediment infilling, accretion, and erosion, as well as potential locations of ice jams. 
We suggest flood waters from ice jams near Emmonak are likely to flow through Anuzukanuk Pass (south of Kwiguk Pass) for the following reasons:

The locations of potential ice jams are immediately downriver, which has historically resulted in flooding over this region.

Observed erosion of the cutbank (fig. 5, "Primary Cutbank") toward Kwiguk Pass from the 1950s to 2010s shows pronounced migration of the Yukon River channel toward this region.

The point bar region is crossed by many abandoned channels at lower elevation than other potential overflow points from the Yukon River (fig. 6).

Anuzukanuk Pass is a small but pre-existing channel, which has the potential to widen and divert discharge after a flood event.

Anuzukanuk Pass is a more direct path to the Bering Sea than the current channel of Kwiguk Pass.

If flood waters were to extend north to Bugomowik Pass through the community of Emmonak (which has occurred historically), flood waters could drain to the north. This direction of flood water release, however, would not likely result in migration of the Yukon River channel: it is much farther to the sea compared to Kwiguk Pass (water will naturally seek the shortest route), and is composed of very minor channels compared to either Kwiguk or Anuzukanuk Pass.

Channel migration due to accretion of one side of a river bank and erosion of a cutbank is generally a slow and ongoing process that can be punctuated by episodic major changes, often due to flood events. Historical changes in river bank location provide insight into how quickly these changes can occur and give timescales for future impacts (which will be discussed in a more local- ized context below). Channel migration events resulting in a meander cutoff or channel avulsion are infrequent and very difficult to predict but can occur over very short timescales. For example, a major flood event that is predicted to occur once in one thousand years may be responsible for the channel change, but may only occur over a few days. While there is potential for major channel changes to occur near Emmonak, the complexity of river dynamics, ice mechanics, materials characteristics, and weather conditions mean the exact path and timing of such events is not predictable with currently available baseline datasets.

\section{Local Erosion}

The main channel of the Yukon River distributary has eroded toward Emmonak, shortening the distance between the main channel and Kwiguk Pass (Map Sheet 1). Main channel Yukon River changes are on the order of kilometers, however, erosion and accretion rates cannot be measured due to the limited availability of suitable data at the regional scale. The point on the east bank of the mouth of Kwiguk Pass that had previously sent river flows to the south and west has totally eroded away, allowing river flow to more directly enter Kwiguk Pass (fig. 5). Kwiguk Pass has narrowed where it departs the main Yukon distributary, and widened just east of Emmonak (Map Sheet 1). It has migrated north (as much as $175 \mathrm{~m}[574 \mathrm{ft}]$ of erosion between 1950 and 2016; table 2; fig. 7) and widened along the riverbank east of the city dock (Map Sheet 1), resulting in erosion near a road, which connects the village to the airport. Projected shoreline positions intersect this road as early as 2020, with an average rate of erosion of $2.03+/-0.52 \mathrm{~m} /$ year $(6.7+/-1.7 \mathrm{ft} /$ year; table 2 ; Map Sheet 2).

Further downstream, riverbank infrastructure may be less impacted by erosion. Shoreline positions migrated toward current infrastructure locations from 1950 to 1980 (table. 2; Map Sheet 1), however, more recent shorelines (20062016) appear more stable (ex. fig. 8). 


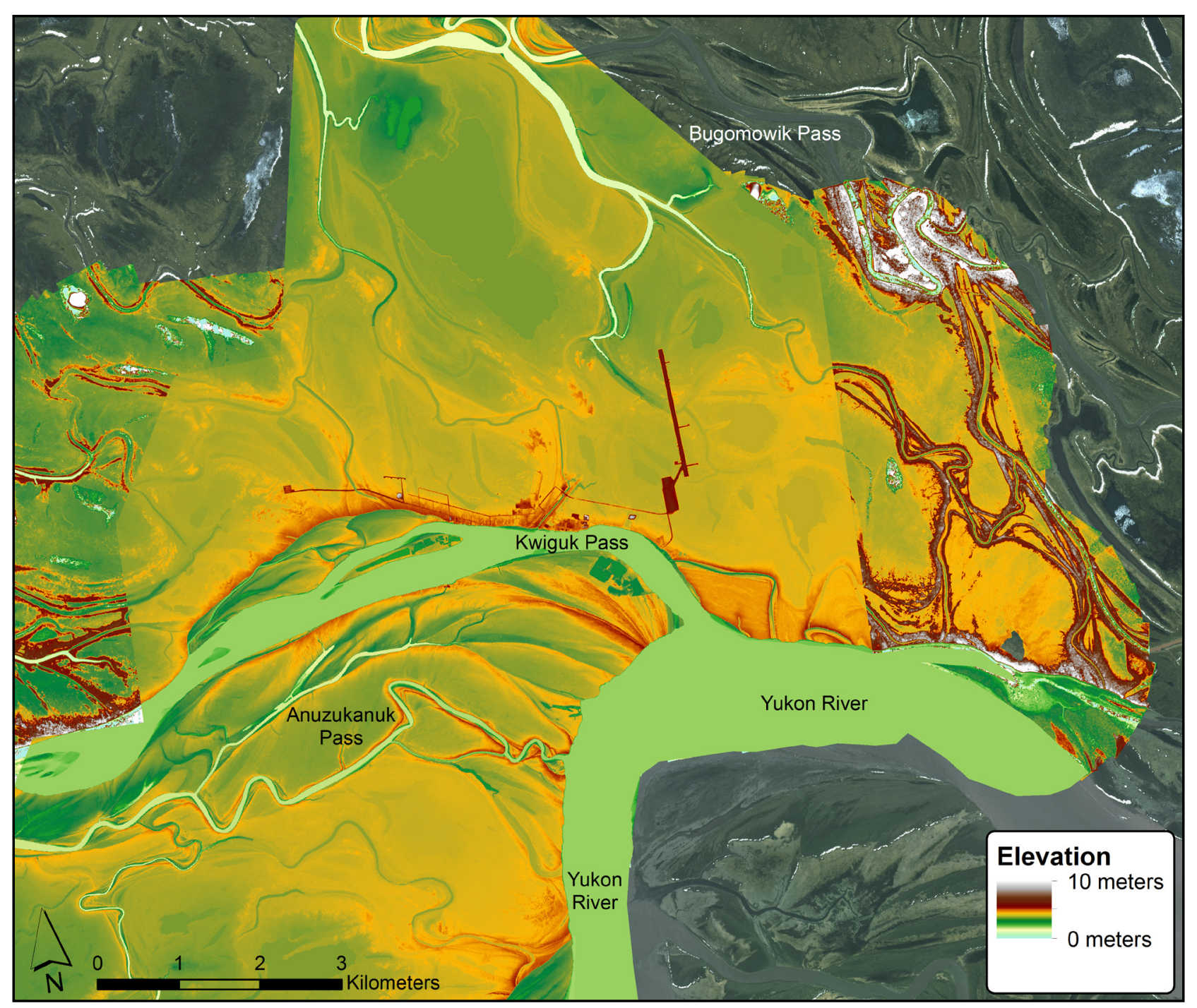

Figure 6. Elevation data for the area surrounding Emmonak, including a lidar bare earth model (middle area; 2016) and a photogrammetrically-derived surface model (noisier data on either side of the lidar data, reflecting the elevation of vegetation), superimposed on a satellite base image (ca. 2010). Anuzukanuk Pass and abandoned channels south of Kwiguk Pass are lower in elevation and thus more direct routes for river flow compared to Bugomowik Pass for anticipated release of potential flood waters, as well as likely locations for channel avulsion due to cutbank erosion.

Uncertainty in the modeled shoreline positions can be due to changes in the trend of shoreline movement. For example, when shoreline positions consistently erode through time, the regression line fits well (constant shoreline trend; fig. 9a); when shoreline movement changes from erosion to accretion or stabilization through time, the regression does not fit well and can result in uncertain model projections (two different shoreline trends; fig. 9b); and when the shoreline has consistently accreted through time, the regression line fits well (constant shoreline trend; fig. 9c). One example of a change in shoreline trend that has resulted in poor model projections is around the city dock. In the area around the city dock, management activities to reduce erosion are visible in the orthoimagery. Rock revetments along with active movement of bank materials have slowed shoreline change rates in recent years (similar to the example in fig. 9b). The projected shorelines along the city dock are likely an over estimate of erosion, given the shoreline stabilization efforts. 
Table 2. Statistics of shoreline change parameters along Emmonak shoreline.

\begin{tabular}{|c|c|c|c|c|c|c|c|c|c|}
\hline \multirow{2}{*}{ Metric Units } & \multicolumn{3}{|c|}{$\begin{array}{c}\text { Weighted Linear Regression Rate of Shore- } \\
\text { line Change (m/year) }\end{array}$} & \multicolumn{4}{c|}{ Net Shoreline Movement (m) } \\
\cline { 2 - 9 } & Average & St. Dev. & Maximum & Minimum & Average & St. Dev. & Maximum & Minimum \\
\hline $\begin{array}{c}\text { East of City } \\
\text { Dock }\end{array}$ & -2.03 & 0.52 & -1.15 & -2.72 & -136.43 & 32.92 & -78.04 & -174.72 \\
\hline In Town & -0.35 & 0.28 & 0.11 & -0.84 & -29.28 & 17.15 & 6.37 & -57.68 \\
\hline Akcuar Slough & -0.52 & 0.75 & 0.61 & -1.64 & -34.36 & 49.04 & 40.27 & -107.69 \\
\hline \multirow{2}{*}{$\begin{array}{c}\text { English } \\
\text { Units }\end{array}$} & Weighted Linear Regression Rate of Shore- & & Net Shoreline Movement (ft) \\
\cline { 2 - 10 } & Average & St. Dev. & Maximum & Minimum & Average & St. Dev. & Maximum & Minimum \\
\hline $\begin{array}{c}\text { East of City } \\
\text { Dock }\end{array}$ & -6.66 & 1.71 & -3.77 & -8.92 & -447.63 & 108.01 & -256.05 & -573.26 \\
\hline $\begin{array}{c}\text { In Town } \\
\text { Ine Change (ft/year) }\end{array}$ & -1.15 & 0.92 & 0.36 & -2.76 & -96.07 & 56.27 & 20.90 & -189.25 \\
\hline Akcuar Slough & -1.71 & 2.46 & 2.00 & -5.38 & -112.74 & 160.90 & 132.13 & -353.33 \\
\hline
\end{tabular}

Positive values represent accretion and negative represent erosion.

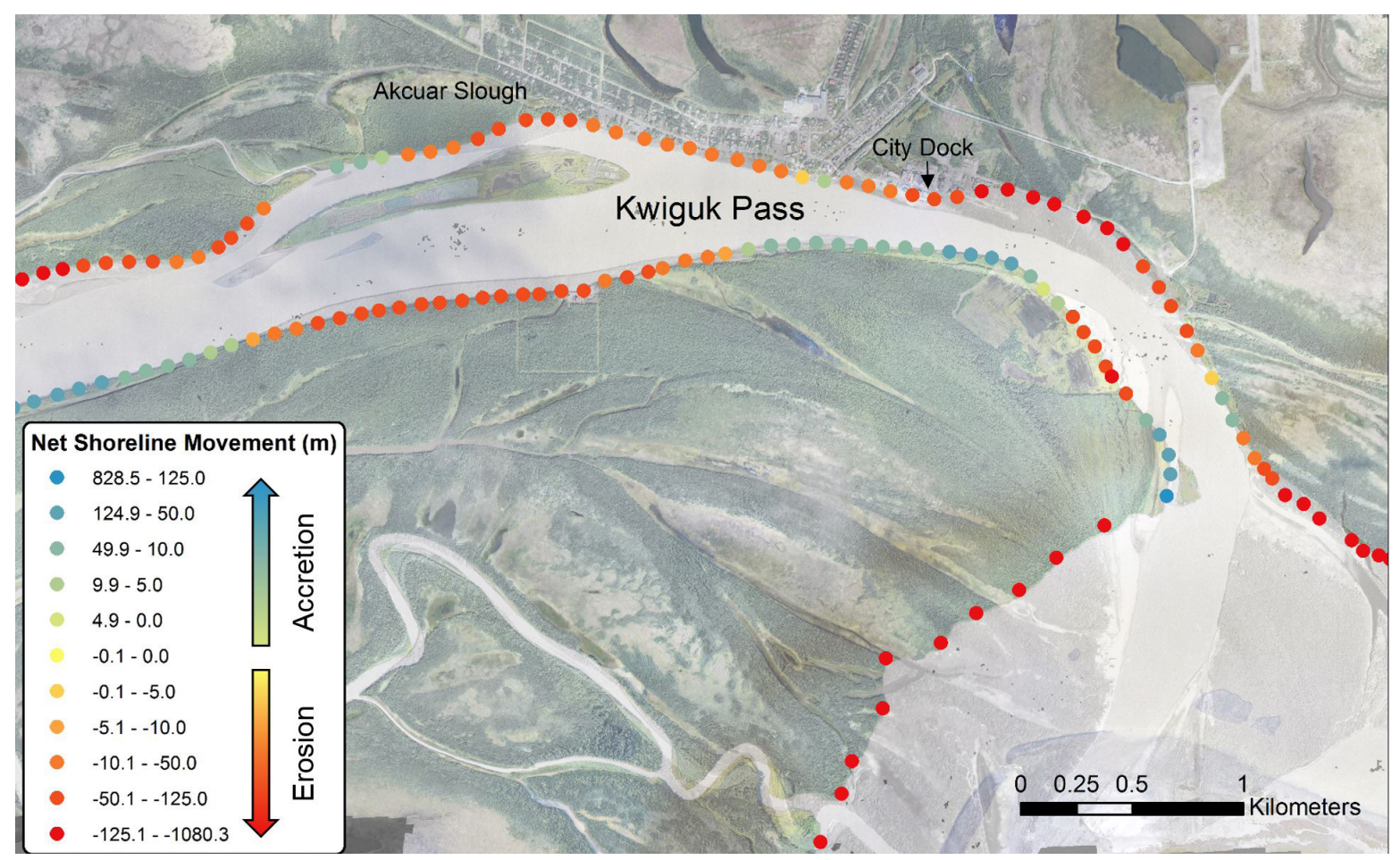

Figure 7. Net shoreline movement (net erosion or accretion) at cross-shore profile locations at the village of Emmonak. Data locations are projected onto the most recent available shoreline position (date varies). Cooler colors show accretion and hotter colors show erosion. Base imagery is the 2015 orthoimage overlain on the 1950 orthoimage. 


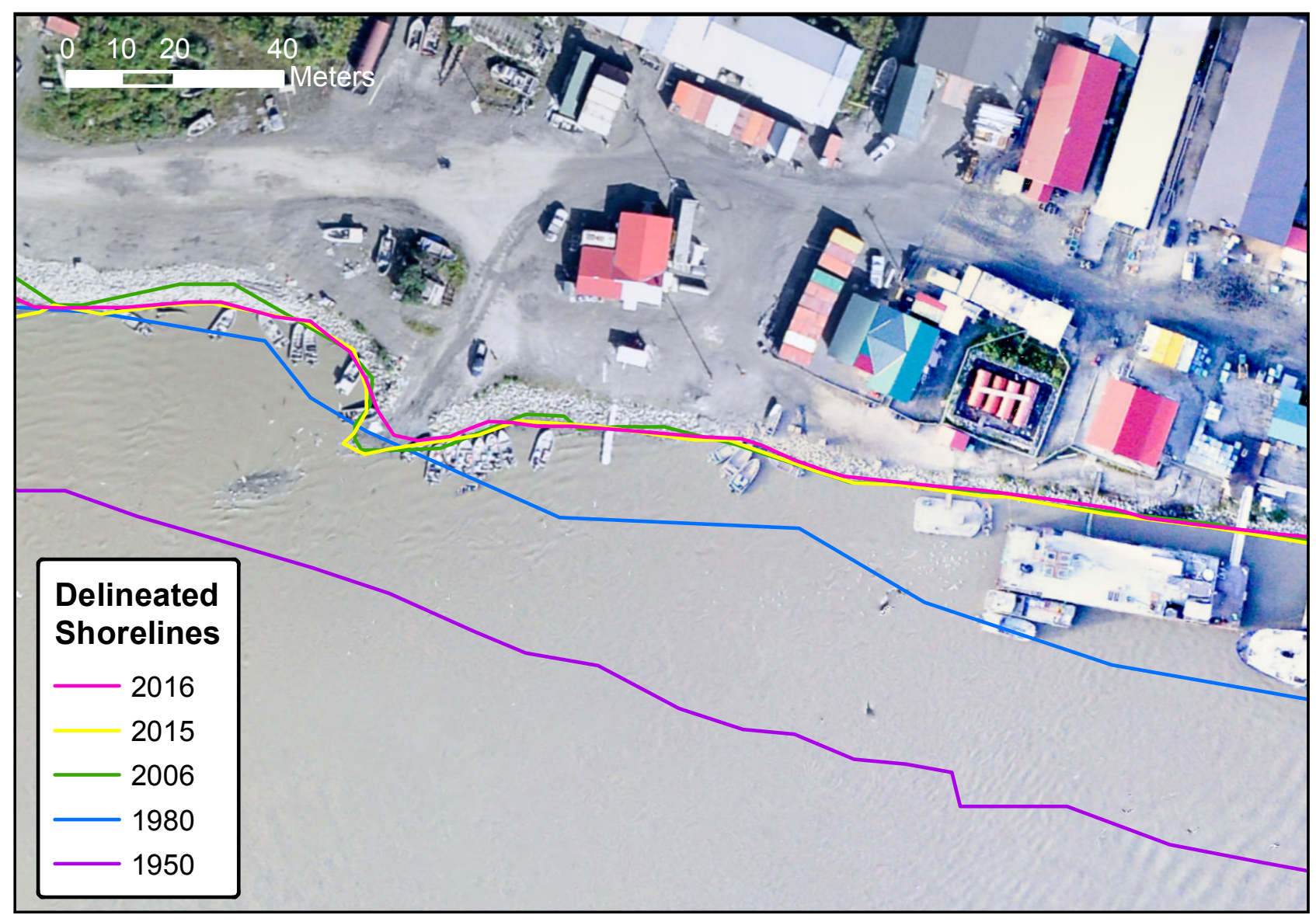

Figure 8. Shoreline positions fronting the city dock at Emmonak, showing shoreline erosion from 19502006, then shoreline stabilization from 2006-2016. Base imagery is the 2015 orthoimage.

River sediment supply, whether from erosion upstream or other factors, has allowed the river bar fronting Emmonak to stabilize. The bar stabilized enough for dense vegetation to form between 1950 and 1980 (Map Sheet 1). Stabilization of the island in Kwiguk Pass has likely pushed flow to the north and south of the island, resulting in erosion on both sides of the river (fig. 6), including Akcuar Slough. The island has been identified as a fish camp site, net storage area, and material site for road building (Alaska Division of Community and Regional Affairs, 2017b). Both erosion and accretion have occurred near Akcuar Slough (NSM of $40.27 \mathrm{~m}$ to $-107.69 \mathrm{~m}$ [132.1 $\mathrm{ft}$ to $-353.3 \mathrm{ft}$ ] between 1950 and 2016; table 2 ), although erosion dominates the area (average
NSM of $-34.36 \mathrm{~m}[112.7 \mathrm{ft}]$ and average WLR erosion rate of $-0.52 \mathrm{~m} /$ year $[1.7 \mathrm{ft} /$ year]; table 2 ).

Downstream of the main community infrastructure, river shorelines have experienced variable widening and narrowing of the channel. These changes are expected to continue due to consistent yet slow (WLR rate of $+/-1 \mathrm{~m} /$ year $[3.3 \mathrm{ft} /$ year]) shoreline trends (1950-2016; Map Sheet 1).

Due to the limited availability of suitable data to analyze river shoreline change, the frequency of flood events or type of flooding was not compared to rates of erosion through time. The frequency of erosion events are also not parsed through the data series, so we are unable to determine the magnitude of erosion that is either episodic or continuous. 


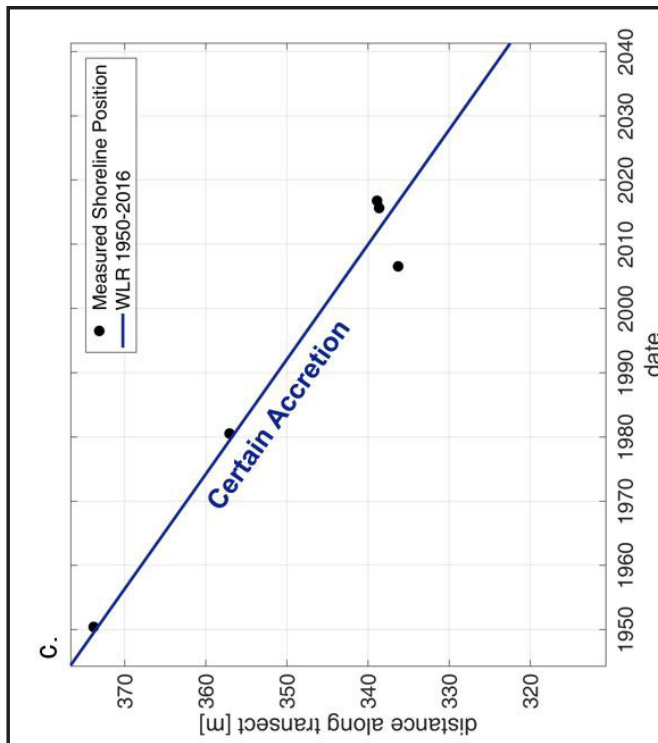

.

U⿺

s

$\stackrel{0}{ \pm}$

을

응

둥

กิ

ํํำ

זे

ㅇํㅇ

$=$

을 ह

은

वे

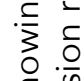

品
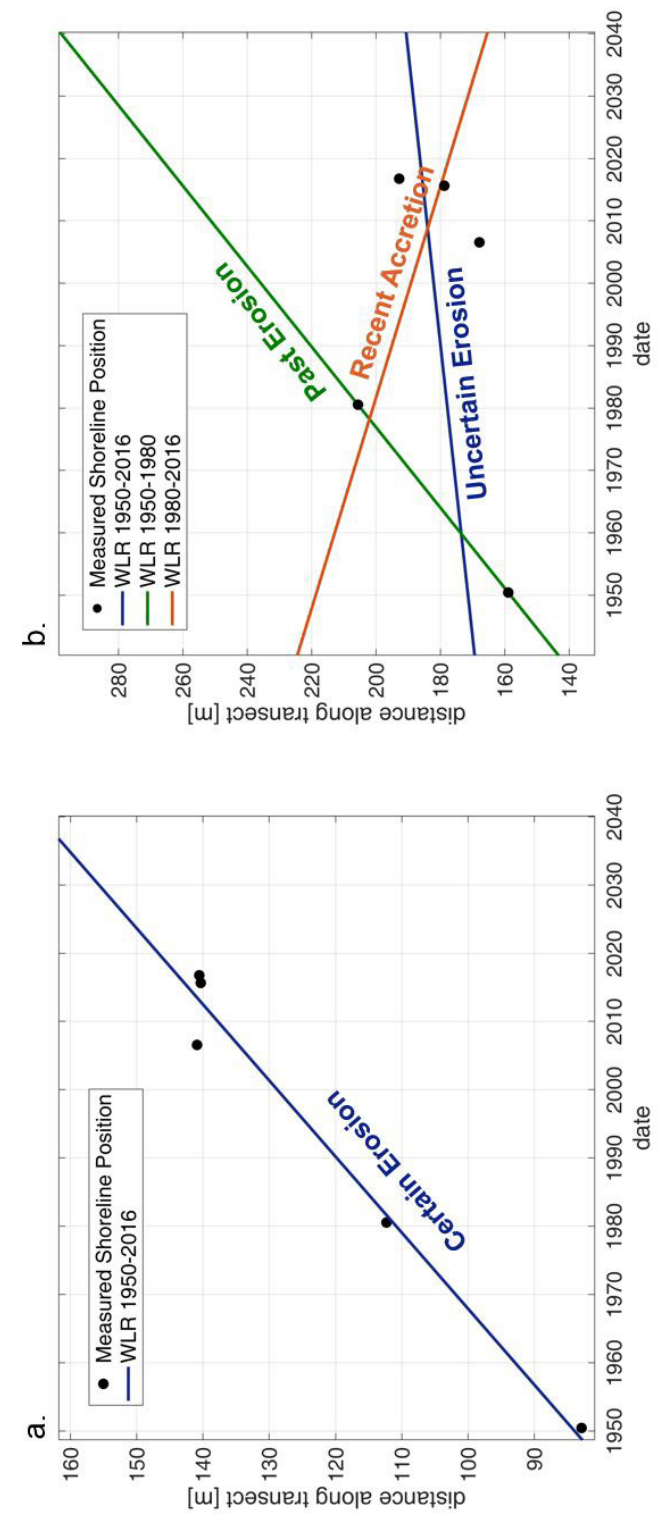

弟

음 록

त市

4

药

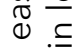

廿

崩

ปั

$\frac{1}{\sigma}$

के

4 우

(1) ำ

के

익

车

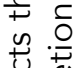

品

त

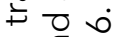

4 $\frac{1}{4} \frac{0}{0}$

w०

0 串

웅 응

o 0 -

능 능

कर 은

을

:

0 .

$\therefore .0 \bar{u}$

(1)

ำ 인

을 을

ज.

a o ज

ब的施

吾高

可高烍 


\section{CONCLUSIONS AND RECOMMENDATIONS}

Emmonak's location on the Yukon Delta makes the community vulnerable to channel migration from the Yukon River at a regional scale as well as from localized erosion in Kwiguk Pass. Major flood events, particularly from ice jams, have the potential to migrate channels and reroute Yukon River discharge across the floodplain. A likely location for flood waters to drain and where morphologic changes would be most apparent is south of Kwiguk Pass through Anuzukanuk Pass and nearby low-elevation abandoned channels. This location is also subject to significant erosion along the Yukon River cutbank that may, over time, result in bypassing of Kwiguk Pass as a cutoff when the river connects the two closest parts of the Kwiguk River bend to form a new channel or occupy Anuzukanuk Pass.

Changes to river morphology could result in less water flowing through Kwiguk Pass, which could impact local commercial and subsistence fishing activities as well as barge access to the community. These potential changes in river morphology are very unpredictable and can occur on a geologic timescale. Since large-scale morphologic changes are difficult to predict, additional studies should be conducted to better understand the potential for channel migration near Emmonak. Elevation data did not fully extend to Bugomowik Pass to the north of the community, which inhibited the ability to determine how floodwaters might flow through this region. Additionally, minimal information is available on historical floods in the region. Historical information that would benefit future studies includes the type of flood event that occurred, the location of ice jams (if appropriate), and flood extent beyond the community location. Future flood events should be documented by mapping flood extents and monitoring river water levels on Kwiguk Pass. Studies to numerically model river dynamics would benefit from additional elevation and bathymetric data of the study area.

Localized erosion of the Yukon River and Kwiguk Pass have the potential to significantly impact community infrastructure. Based on historical orthoimagery and lidar, rates of shoreline change on Kwiguk Pass are generally on the order of $+/-1 \mathrm{~m} /$ year $(3.3 \mathrm{ft} /$ year). Certain areas experience higher rates of erosion, including the river shoreline east of the city dock (average $2.03 \mathrm{~m}$ /year [6.7 ft/ year]). Road infrastructure along the river to the east of the city dock is expected to experience significant impacts from erosion by 2020. Erosion of infrastructure can be mitigated through constructing a hardened river bank, moving, or rebuilding infrastructure. Although hardened structures provide immediate protection from erosion events, they have limited lifetimes and can redirect river energy to cause erosion downstream. Continued monitoring and reanalysis of erosion rates will improve the understanding of whether or not erosion rates are increasing or decreasing through time and whether erosion is episodic or continuous.

\section{ACKNOWLEDGMENTS}

This research was funded by the Federal Emergency Management Agency's Cooperating Technical Partners Program (award EMS-2016CA-00006). Reviews by Sally Russell Cox and De Anne Stevens. 


\section{REFERENCES}

Alaska Division of Community and Regional Affairs (DCRA), 2017a, Community Database Online, Emmonak Community Profile: State of Alaska DCRA website, last viewed 03/14/2018. https://www.commerce.alaska.gov/dcra/ DCRAExternal/community/Details/a450b1ef2187-4c99-8dc7-3d059027c810

2017b, Community Profile Imagery, Emmonak Community Profile Imagery State of Alaska DCRA website, last viewed 03/14/2018. http://dcced.maps.arcgis.com/apps/ webappviewer/index.html? id=be 243 ec0 1 d784c3eb309f61aa6d2d392

City of Emmonak, 2014, City of Emmonak, Alaska: Local Hazards Mitigation Plan: City of Emmonak, 116 p. https://www.commerce. alaska.gov/dcra/DCRARepoExt/RepoPubs/ Plans/Emmonak\%20LHMP\%202014.pdf

DGGS Staff, 2013, Elevation Datasets of Alaska: Alaska Division of Geological \& Geophysical Surveys Digital Data Series 4, http://maps.dggs.alaska.gov/eleationdata/. http://doi.org/10.14509/25239

Douglas, D.C., 2010, Arctic sea ice decline: Projected changes in timing and extent of sea ice in the Bering and Chukchi seas: U.S. Geological Survey Open-File Report 2010-1176, 32 p. https://pubs.usgs.gov/of/2010/1176/pdf/ ofr20101176.pdf

Gould, A.I., Kinsman, N.E.M., and Hendricks, M.D., 2015, Guide to projected shoreline positions in the Alaska shoreline change tool, in DGGS Staff, Alaska shoreline change tool: Alaska Division of Geological \& Geophysical Surveys Miscellaneous Publication 158, 11 p. http://doi.org/10.14509/29503

Jorgenson, T., Yoshikawa, K., Kanevskiy, M., Shur, Y., Romanovsky, V., Marchenko, S., Grosse, G., Brown, J., and Jones, B., 2008, Permafrost characteristics of Alaska: Ninth International Conference on Permafrost, June 29-July 3, 2008, Fairbanks, Alaska. http://permafrost.gi.alaska. edu/sites/default/files/AlaskaPermafrostMap_ Front_Dec2008_Jorgenson_etal_2008.pdf
Kinsman, N.E.M., and Gould, A.I., 2014, Contemporary shoreline retreat rates at Meshik in Port Heiden, Alaska: Alaska Division of Geological \& Geophysical Surveys Preliminary Interpretive Report 2014-4, 21 p. http://doi. org/10.14509/27321

Macander, M.J., Swingley, C.S., and Spencer, S.R., 2014, Extensive mapping of Bering Sea and Gulf of Alaska coastal change by Landsat timeseries analysis, 1972-2013; Phase II: Full study area, Western Alaska Landscape Conservation Cooperative Project 2013-24: ABR, Inc., Final Project Report, 81 p. https://westernalaskalcc. org/projects/Lists/Project\%20 Products/ Attachments/69/Extensive_Mapping_of_ Coastal_Change_WALCC_1972-2013_Final_ Report_web.pdf

Overbeck, J.R., Hendricks, M.D., and Kinsman, N.E.M., 2016, Photogrammetric digital surface models and orthoimagery for 26 coastal communities of western Alaska: Alaska Division of Geological \& Geophysical Surveys Raw Data File 2016-1, 3 p. http://doi. org/10.14509/29548

STARR, 2015, Discovery Report FEMA Region X: City of Emmonak, Yukon Delta Watershed, Alaska, STARR. https://www.commerce.alaska. gov/web/Portals/4/pub/Discovery_ReportEmmonak_City_of-Yukon_Delta_Watershed. pdf

Theiler, E.R., Himmelstoss, E.A., Zichichi, J.L., and Ergul, Ayhan, 2009, The Digital Shoreline Analysis System (DSAS) version 4.0-An ArcGIS extension for calculating shoreline change: U.S. Geological Survey Open-File Report 2008-1278. https://pubs.er.usgs.gov/ publication/ofr20081278

Vermaire, J. C., Pisaric, M. F.J., Thienpont, J. R., Mustaphi, C. J. C., Kokelf, S. V., and Smol, J. P., 2013, Arctic climate warming and sea ice declines lead to increased storm surge activity: Geophysical Research Letters, v. 40, p. 1,3861,390. http://doi.org/10.1002/grl.50191 